\title{
Pemberdayaan Masyarakat dalam Pemanfaatan Kalakai (Stenochlaena palustris (Burm. F) Bedd.) sebagai Antioksidan Alami pada Kelompok Ibu-Ibu PKK di Kelurahan Palam, Kecamatan Cempaka, Banjarbaru
}

\author{
Community Empowerment in the Utilization of Kalakai (Stenochlaena palustris (Burm. F) \\ Bedd.) as a Natural Antioxidant to PKK Group in Palam Village, Cempaka District, \\ Banjarbaru
}

\section{Ratna Restapaty ${ }^{1^{*}}$ \\ Dyera Forestryana ${ }^{1}$ \\ Hafiz Ramadhan 1 \\ Revita Saputri ${ }^{2}$ \\ Satrio Wibowo Rahmatullah ${ }^{3}$ \\ Rahmayanti Fitriah 1 \\ 1Pharmacy Undergraduate Study Program, Sekolah Tinggi Ilmu Kesehatan Borneo Lestari, Banjarbaru, South Kalimantan, Indonesia \\ 2Pharmacy Diploma Study Program, Sekolah Tinggi Ilmu Kesehatan Borneo Lestari, Banjarbaru, South Kalimantan, Indonesia \\ 3Pharmacist Professional Education Study Program, Sekolah Tinggi Ilmu Kesehatan Borneo Lestari, Banjarbaru, South Kalimantan, Indonesia}

email: ratnarestapaty@gmail.com

Kata Kunci

Antioksidan alami

Kalakai

Olahan pangan

Keywords:

Natural antioxidant

Kalakai

Processed food

Received: August 2021

Accepted: September 2021

Published: October 2021

\begin{abstract}
Abstrak
Pencegahan penyebaran Covid-19 merupakan upaya esensial di saat masih tingginya angka positif \& kematian. Pemberian edukasi pencegahan penyebaran Covid-19 selalu dilaksanakan dengan program berbasis kesadaran masyarakat menjaga imunitas tubuh. Pengabdian masyarakat dengan memanfaatkan kalakai sebagai antioksidan alami menjadi salah satu alternatif sebagi wujud mendukung pemerintah. Kalakai (Stenochlaena palustris (Burm. F) Bedd.)) merupakan tanaman paku-pakuan yang merupakan salah satu tanaman dengan antioksidan khas Kalimantan yang sejarahnya digunakan sebagai obat tradisional. Pemanfaatan potensi tersebut dapat dilakukan dan diterapkan melalui pemberdayaan masyarakat Kelurahan Palam, Kecamatan CempakaBanjarbaru, dimana banyak tanaman Kalakai yang tumbuh liar. Permasalahan yang ditemukan antara lain kurangnya informasi dan minimnya keterampilan warga dalam pengolahan pangan berbahan dasar tanaman Kalakai terutama dalam hal pengolahan pangan dengan antioksidan tinggi dalam bentuk penyuluhan kepada kelompok ibu-ibu PKK Kelurahan Palam Cempaka-Banjarbaru. Metode kegiatan yang dilaksanakan adalah penyuluan pemberian edukasi yakni teori antioksidan dan potensi Kalakai, dan demontrasi/praktek langsung pembuatan sirup, teh dan permen kalakai. Diharapkan warga mengembangkan produk olahan pangan menjadi UMKM khas kelurahan Palam sebagai peluang usaha sehingga dapat meningkatkan taraf hidup masyarakat.
\end{abstract}

\begin{abstract}
Prevention of the spread of Covid-19 is an essential effort when there are still highly favorable rates \& deaths. The provision of education to prevent the spread of Covid-19 is always carried out with community awarenessbased programs to maintain immunity. Community service by utilizing kalakai as a natural antioxidant becomes one of the alternatives to support the government. Kalakai (Stenochlaena palustris (Burm. F) Bedd.)) is a nail plant that is one of the plants with antioxidants typical of Kalimantan whose history is used as traditional medicine. This potential can be utilized and applied through the empowerment of the community of Palam Village, Cempaka Subdistrict, where many Kalakai plants grow wild. The problems found include lack of information and lack of skills of citizens in food processing based on Kalakai plants, especially in terms of food processing with high antioxidants in the form of counseling to the PKK mothers group Palam Cempaka-Banjarbaru Village. The activity method is the extension of educational provision, namely the theory of antioxidants and the potential of Kalakai, and the direct demonstration/practice of making syrups, teas, and kalakai candy. Residents expect to develop processed food products into UMKM, especially of Palam village, as a business opportunity to improve people's living standards.
\end{abstract} Palangkaraya. This is Open Access article under the CC-BY-SA License (http://creativecommons.org/licenses/by-sa/4.0/). DOI: https://doi.org/10.33084/pengabdianmu.v6i6.2835 


\section{PENDAHULUAN}

WHO menetapkan status global emergency pada kasus virus Corona ini dan pada 11 Februari 2020 WHO menamakannya sebagai COVID-19 (Handayani et al., 2020). Kasus kematian akibat Covid-19 di Kalimantan Selatan sampai saat ini sudah mencapai 1.057 darijumlah kasus positif sebanyak 35.723 (per tanggal 24 Juni 2021) berdasarkan data dari Dinas Kesehatan Provinsi Kalimantan Selatan (Dinas Kesehatan Provinsi Kalimantan Selatan, 2021). Laju penularan menjadi kekhawatiran bersama bagi seluruh kalangan masyarakat. Pemberian edukasi pencegahan penularan Covid-19 selalu harus dilaksanakan, salah satunya meningkatkan daya tahan tubuh dengan pemanfaatan bahan alam sebagai antioksidan (Ryadha et al., 2021).

Antioksidan dapat ditemukan dalam bahan pangan manapun, baik di buah-buahan, sayuran, biji-bijian, maupun hewani. Sebuah studi baru menjelaskan bahwa pangan nabati umumnya memiliki kadar antioksida yang tinggi dibandingkan pangan hewani dan produk pangan campuran seperti minuman seperti daun teh Umumnya, antioksidan ditemukan pada bahan pangan dalam bentuk vitamin $\mathrm{C}$, vitamin $\mathrm{E}$, betakaroten, zinc, selenium, SOD, flavonoid dan bentuk lainnya (Sen \& Chakraborty, 2011).

Kalakai (Stenochlaena palustris (Burm. F) Bedd.)) merupakan salah satu tumbuhan berkhasiat bagi kesehatan yang berasal dari jenis tumbuhan pakupakuan. Kalakai merupakan paku rawa yang tumbuh tegak ke atas, dengan daun fertil yang jumlahnya terbatas, berbentuk menyirip. Kalakai dapat ditemukan di tanah gambut maupun tanah berpasir. Penelitian sebelumnya telah menjelaskan bahwa kalakai atau pakis (daun dan batang) mengandung zat besi yang sangat tinggi sehingga baik digunakan pada penderita anemia (Adawiyah \& Rizki, 2018).

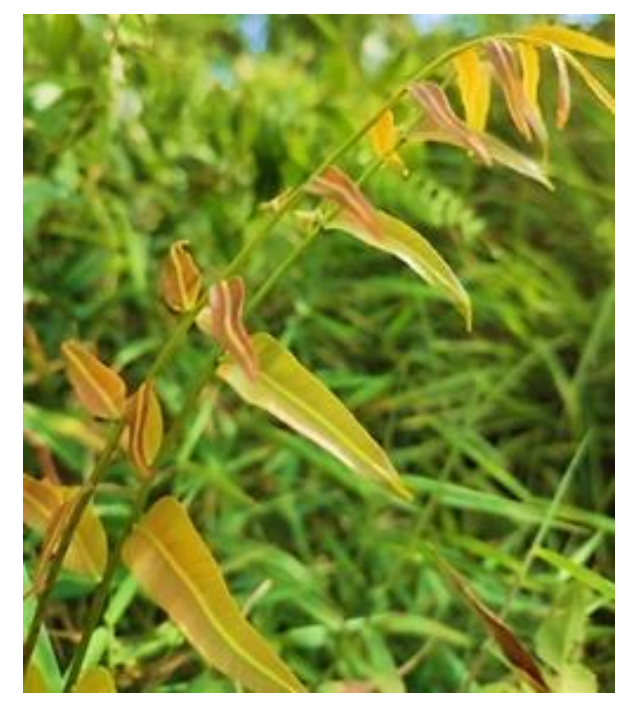

Gambar 1. Tanaman Kalakai

Kalakai berpotensi meningkatkan daya tahan tubuh karena aktivitas antioksidan yang dihasilkannya sangat tinggi. Potensi antioksidannya sangat kuat pada bagian akar ( IC $_{50}$ 19,06 ppm) dikarenakan kandungan total fenolik dan flavonoid yang tinggi (Adawiyah \& Rizki, 2018). Kalakai merupakan salah satu tanaman khas Kalimantan yang sejarahnya digunakan sebagai obat tradisional. Tanaman ini berkhasiat mengobati banyak penyakit serta membantu memperlancar ASI pada ibu menyusui karena dapat mencukupi kebutuhan zat besi (Fe) pada ibu menyusui dan balita, selain itu dapat meredakan demam, mengobati sakit kulit, dan juga sebagai pencuci perut. Kandungan gizi Kalakai merah yaitu protein (2,36\%), serat kasar (4,44\%), lemak (0,11\%), abu (1,19\%), air (89,09\%), vitamin, mineral serta fitokimia lainnya yang bermanfaat untuk kesehatan. Kalakai mengandung senyawa atau zat yang termasuk pangan fungsional (Indrayanti et al., 2016; Mashar \& Annah, 2020).

Kalakai sering dimanfaatkan sebagai pelengkap makanan (sayuran), padahal tanaman ini memiliki potensi sebagai antioksidan dan dapat dimanfaatkan melalui pengolahan pangan lokal. Selain dapat berguna sebagai antioksidan bagi kesehatan masyarakat dalam masa pandemi Covid-19 ini, kalakai dapat dimanfaatkan 
sebagai keanekaragaman konsumsi pangan lokal di masyarakat. Pemanfaatan potensi tersebut dapat dilakukan dan diterapkan melalui pemberdayaan masyarakat lokal khususnya Kelurahan Palam, Kecamatan Cempaka Banjarbaru, dimana banyak tanaman Kalakai tumbuh dengan subur. Oleh karena itu, sebagai perwujudan nyata keperdulian terhadap pentingnya memutus mata rantai dan mencegah penyebaran Covid-19, maka STIKES Borneo Lestari Banjarbaru melalui pengabdian masyarakat ini diharapkan dapat memberikan edukasi dengan kegiatan pembuatan dan pemanfaatan tanaman Kalakai sebagai bahan minuman dan pangan seperti sirup, teh dan permen yang punya nilai ekonomis. Kegiatan ini diharapkan bahwa Kalakai tidak hanya digunakan sebagai pelengkap makanan tetapi juga meningkatkan kesehatan masyarakat, bahkan diharapkan dapat menjadi olahan pangan yang dapat membantu perekonomian masyarakat sekitar (Mahdiyah et al., 2021; Fahruni et al., 2018).

Pencegahan penyebaran penularan Covid-19 merupakan upaya esensial di saat masih tingginya angka kematian dan positif Covid-19 yang diiringi dengan semakin meningkatnya penyebaran varian delta (Harapan et al., 2020). Untuk mengatasi hal tersebut program yang berbasis kesadaran masyarakat untuk memanfaatkan bahan alam sebagai antioksidan alami menjadi salah satu alternatif sebagi wujud mendukung pemerintah. Selain hal tersebut, perlu dilakukan mobilisasi masyarakat dalam membiasakan hidup sehat sesuai dengan tujuan program menekan penyebaran Covid-19. Kelurahan Palam, belum dilakukan pengoptimalisasi pemanfaatan bahan alam sebagai antioksidan alami yang berbasis masyarakat. Hal tersebut merupakan solusi dan perlu dilakukan inisiasi mulai dari kelompok masyarakat paling kecil seperti kelompok ibu-ibu PKK. Kegiatan Pengabdian ini dilaksanakan sebagai solusi permasalahan yang ada di masyarakat, antara lain sebagai berikut. Memberikan edukasi tentang pentingnya antioksidan alami dalam menjaga daya tahan tubuh di masa pandemi Covid-19 dan memberikan pelatihan pembuatan olahan pangan dari tanaman Kalakai sebagai antioksidan yang berpotensi untuk meningkatkan daya tahan tubuh dengan mendemontrasikan pembuatan sirup, teh dan permen.

\section{METODOLOGI}

Kegiatan Pengabdian Masyarakat dilakukan dengan memberi materi (edukasi) tentang antioksidan alami, khasiat kalakai dan praktek atau demo pembuatan sirup, teh dan permen dari bahan kalakai dengan tujuan untuk mengenalkan ke masyarakat tentang teknik pengolahan dan pemanfaatan tanaman dari alam dengan cara yang sederhana. Kegiatan ini merupakan kegiatan program pengabdian pada masyarakat dengan tahapan kegiatan sebagai berikut: dimulai dengan survey tempat, proses perizinan, persiapan alat bahan untuk pembuatan infusa dan pemilihan formula yang tepat di laboratorium Tehnologi Farmasi STIKES Borneo Lestari, penyusunan materi edukasi dan demo pembuatan sirup, teh permen. Kegiatan utama adalah penyuluhan dengan materi mengenai pemanfaatan kalakai sebagai antioksidan berupa sirup dan permen.

Kegiatan dilanjutkan dengan pengambilan data dari dan analisis data. Pengambilan data dilakukan dengan pemberian kuesioner dengan google form pada Kelompok Ibu-Ibu PKK yang mengikuti kegiatan penyuluhan. Data yang diperoleh kemudian direkapitulasi untuk dilanjutkan dengan analisis.

\section{HASIL DAN PEMBAHASAN}

Kegiatan pengabdian masyarakat ini melibatkan tim dosen dan mahasiswa sebagai pelaksana kegiatan. 
Peserta kegiatan adalah kelompok Ibu-Ibu PKK Kelurahan Palam Kecamatan Cempaka. Bentuk kegiatan berupa penyuluhan tentang antioksidan alami yang diperoleh dari khasiat tanaman kalakai. Tanaman kalakai yang dapat digunakan sebagai sirup, teh dan permen, kemudian kegiatan dilanjutkan demo pembuatan beberapa sediaan minuman kalakai, sirup kental, teh dan permen.

Penyuluhan dilaksanakan bersama Ibu-ibu PKK dengan pemaparan materi pemanfaatan dan pembuatan olahan pangan dari kalakai yang mengandung antioksidan penting untuk menjaga imunitas tubuh di tengah pandemi. Peningkatan penyebaran Covid-19 menyebabkan masyarakat mencari cara yang tepat untuk mengatasi penyebaran virus. Salah satunya upaya untuk menjaga daya tahan tubuh dengan mengkonsumsi makanan dan minuman yang mengandung antioksidan alami supaya terhindar dari berbagai macam virus, termasuk Covid-19. Ibu-ibu PKK terlihat antusias memahami penjelasan tentang antioksidan alami oleh Tim dosen seperti pada Gambar 2 berikut.

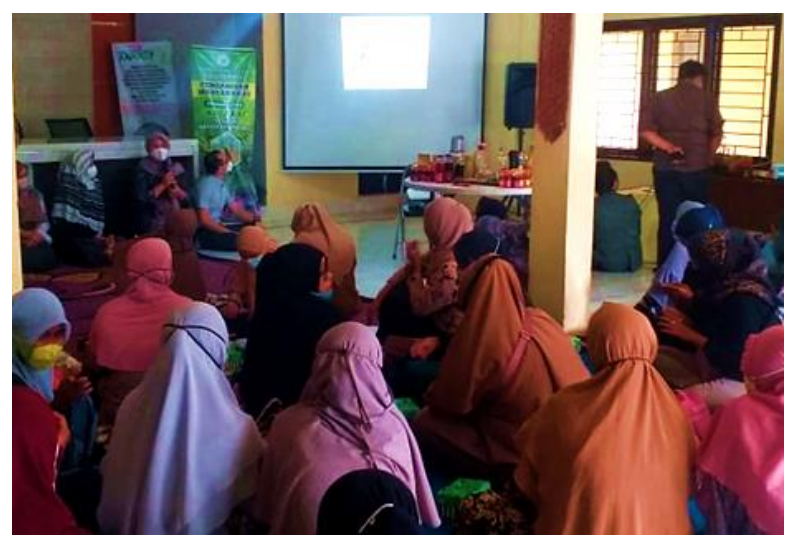

Gambar 2. Pemaparan materi edukasi masyarakat tentang antioksidan dan potensi kalakai

Gambar 2 menunjukkan ibu-ibu PKK memperhatikan materi yang di jelaskan oleh tim dosen tentang antioksidan alami dengan menggunakan media power point yang menarik dan memutar video pembuatan infusa. Asupan antioksidan dari luar dapat berupa antioksidan alami maupun sintetis. Antioksidan alami banyak terkandung dalam buah-buahan dan sayursayuran, serta ditemukan juga pada kacang-kacangan, biji-bijian, teh, dan produk makanan lainnya. Studi terbaru menjelaskan bahwa produk pangan nabati umumnya memiliki kandungan antioksidan yang lebih tinggi dibandingkan produk pangan hewani (Sen \& Chakraborty, 2011). Kalakai berpotensi meningkatkan daya tahan tubuh karena aktivitas antioksidan yang dihasilkannya sangat tinggi. Daun kalakai memiliki potensi yang sangat kuat sebagai antioksidan bahkan dapat dijadikan sediaan minuman fungsional yang berkhasiat antioksidan tinggi jika dikombinasikan dengan tanaman penghasil antioksidan lain seperti jahe (Juliani et al., 2019).

Kegiatan pra demontrasi dilakukan oleh Tim Dosen (TD) dan mahasiswa STIKES Borneo Lestari yang melaksanakan kegiatan persiapan pembuatan produk dimulai dengan tahap awal tanaman kalakai di sortasi basah dengan memisahkan bagian akar, daun dan batang kalakai dan dijemur di bawah sinar matahari, sortasi kering. Daun kering kemudian dihaluskan dengan blender dan kemudian diayak. Tahap selanjutnya yakni membuat infusa dengan memanaskan campuran serbuk kalakai dan air pada suhu $90^{\circ} \mathrm{C}$ kemudian dilakukan penyaringan untuk mengambil air yang bersih tanpa endapan.

Tim dosen selanjutnya memilih formulasi yang tepat untuk olahan sirup, teh dan permen dengan beberapa kali percobaan di Laboratorium Teknologi Farmasi STIKES Borneo Lestari Banjarbaru. Kegiatan selanjutnya setelah memberikan edukasi wawasan tentang antioksidan dan potensi kalakai, yakni demontrasi pembuatan sirup, teh dan permen. Ibu-ibu PKK terlihat antusias memahami proses pembuatannya,seperti pada Gambar 3. 


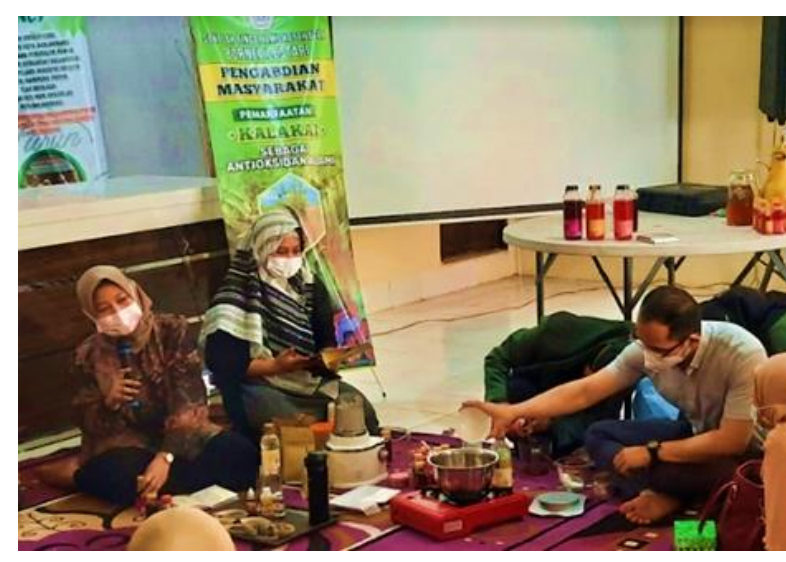

Gambar 3. Demontrasi pembuatan sirup, teh dan permen kalakai

Gambar 3 menunjukkan kegiatan demostrasi pembuatan sirup, teh dan permen kalakai oleh Tim Dosen dan Tim Mahasiswa. Masyarakat sangat senang karena dalam kegiatan ini mendapatkan kesempatan untuk menikmati bagaimana rasa hasil dari demontrasi pembuatan minuman. Produk sirup dan permen ditunjukkan pada Gambar 4 berikut.

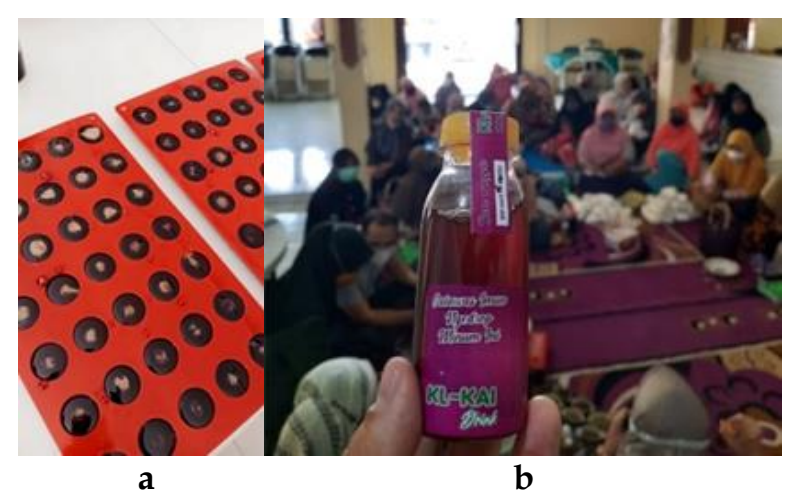

Gambar 4. (a) Produk formulasi permen dimaksukkan dalam cetakan dan (b) sirup kalakai yang sudah dikemas $100 \mathrm{ml}$

Pertanyaan pada kuesioner dalam google form yang diisi kelompok PKK adalah sebagai berikut:

1. Saya mengetahui tentang manfaat antioksidan yang perlukan di tengah pandemi Covid-19.

2. Saya sebelumnya pernah mendapatkan materi edukasi kepada masyarakat tentang pentingnya menjaga kesehatan melalui penggunaan antioksidan alami untuk meningkatkan daya tahan tubuh.

3. Saya sebelumnya pernah mengikuti pelatihan pembuatan olahan pangan dari tanaman Kalakai sebagai antioksidan yang berorientasi untuk meningkatkan daya tahan tubuh

4. Saya pernah menggunakan bahan alam sebagai antioksidan? (Bila pernah) tuliskan nama tumbuhan yang digunakan.

5. Saya mengetahui kandungan gizi dari tanaman Kalakai antara lain, kaya akan serat, protein dan vitamin.

6. Saya kurang senang mengkonsumsi minuman kesehatan dari bahan alami karena rasanya pahit.

7. Saya jarang memanfaatkan kalakai untuk sayuran saja.

8. Saya pernah memanfaatkan kalakai sebagai minuman kesehatan.

9. Saya belum pernah mengkonsumsi permen berbahan kalakai.

10. Wilayah dikelurahan tempat tinggal saya terdapat banyak tanaman kalakai tumbuh liar.

11. Wilayah dikelurahan tempat tinggal saya terdapat banyak tanaman kalakai tumbuh liar.

12. Saya belum mengetahui bahwa tanaman kalakai yang dapat dimanfaatkan sebagai minuman (Sirup) yakni daunnya saja.

13. Saya belum pernah mengetahui sebelumnya bahwa akar dan batang tanaman Kalakai dapat dimanfaatkan sebagai produk pangan lainnya.

14. Saya beraktivitas tinggi setiap hari sehingga saya membiasakan hidup sehat sesuai dengan tujuan program menekan penyebaran Covid-19.

15. Apakah anda pernah menggunakan bahan alam untuk tujuan lainnya? Atau untuk mengobati penyakit? Bila Pernah, mohon tuliskan jenis tanaman dan khasiatnya.

Kegiatan pengabdian masyarakat ini diikuti oleh 38 ibuibu PKK yang sebagian besar beraktivitas sebagai ibu rumah tangga hal tersebut ditunjukkan dengan diagram pada Gambar 5 berikut. 


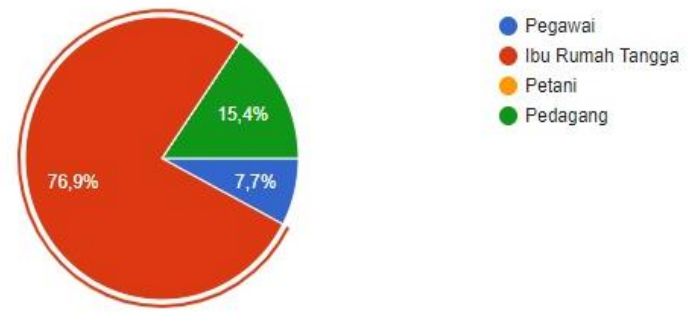

Gambar 5. Jenis pekerjaan kelompok ibu-ibu PKK

Gambar 5 menunjukkan prosentase $(76,9 \%)$ dari 36 orang beraktifitas sebagai ibu rumah tangga, 15,4\% berdagang dan $7,7 \%$ yang menjadi pegawai. Hasil pertanyaan lainnya ditunjukkan pada Gambar 6 berikut.
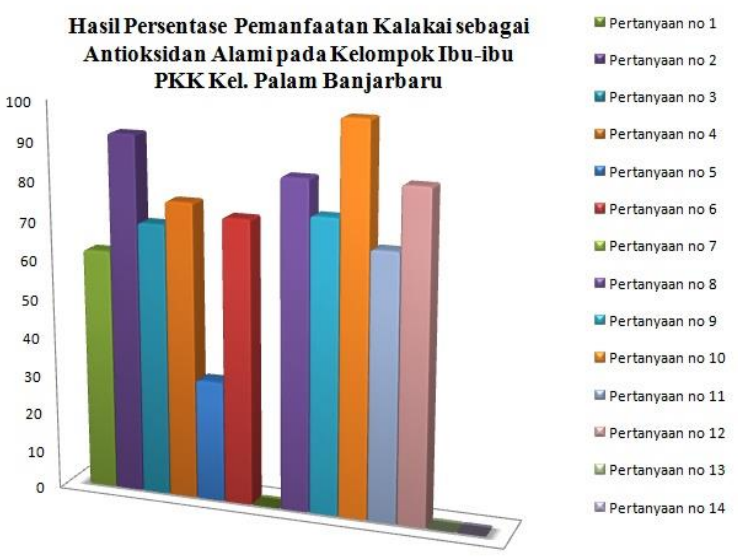

Gambar 6. Persentase Pemanfaatan Kalakai Sebagai Antioksidan Alami

Gambar 6 menunjukkan prosentase sebanyak (62\%) ibuibu mengetahui manfaat antioksidan yang diperlukan di tengah pandemi. Responden mengakui belum pernah mendapatkan materi penyuluhan tentang pentingnya menjaga kesehatan dengan antioksidan alami untuk meningkatkan imunitas tubuh sebanyak 92\%, sedangkan $70 \%$ ibu-ibu kel Palam belum pernah mengikuti pelatihan pembuatan pembuatan olahan pangan dari tanaman Kalakai sebagai antioksidan yang berorientasi untuk meningkatkan daya tahan tubuh. Sehingga $68 \%$ belum mengetahui kandungan gizi dari tanaman Kalakai antara lain, kaya akan serat, protein dan vitamin.
Hasil dari pertanyaan selanjutnya bahwa sebanyak $84 \%$ masyarakat belum mengetahui bahwa tanaman daun kalakai dapat dimanfaatkan sebagai minuman (Sirup), keran sebian besar tanaman kalakai dikonsumsi untuk sayur. Oleh karena itu sebanyak 91,2 \% responde belum pernah mengetahui bahwa akar dan batang tanaman Kalakai dapat dimanfaatkan sebagai produk pangan lainnya. Hasil menunjukkan bahwa sebanyak 84,7\% responden beraktivitas tinggi setiap hari sehingga harus membiasakan hidup sehat sesuai dengan tujuan program untuk menekan penyebaran penyakit Covid19.

Keuntungan yang dapat diperoleh oleh masyarakat setelah mengikuti kegiatan pengabdian masyarakat ini, selain mendapatkan informasi mengenai antioksian alami dan manfaat kalakai mendapat inspirasi mengenai pengolahannya seperti sirup, teh dan permen, yang bernilai ekonomis karena dapat di jual sehingga bisa meningkatkan taraf hidup masyarakat.

\section{KESIMPULAN}

Kegiatan pengabdian masyarakat dilakukan di kelurahan Palam kecamatan Cempaka Banjarbaru telah dilaksanakan dengan baik, dengan melibatkan tim dosen dan mahasiswa sebagai pelaksana kegiatan. Peserta kegiatan adalah kelompok ibu-ibu PKK di kelurahan Palam dengan mendapatkan wawasan baru tentang antioksidan alami, khasiat kalakai dan demontrasi pembuatan pengolahan sirup, teh dan permen. Saran dalam kegiatan ini yakni perlu dilakukan kegiatan lanjutan untuk kegiatan pengabdian masyarakat dengan melibatkan instansi lain yang terkait dalam mengembangkan produk olahan pangan menjadi UMKM khas kelurahan Palam dalam jumlah yang lebih besar, sehingga dapat meningkatkan taraf hidup masyarakat. 


\section{UCAPAN TERIMA KASIH}

Penulis berterimakasih kepada LPPM, citivitas akademik STIKES Borneo Lestari, Ketua kelompok PKK dan Kepala Kelurahan Palam yang telah membantu pelaksanaan kegiatan Pengabdian Masyarakat di Kelurahan Palam, Kecamatan Cempaka- Banjarbaru.

\section{REFERENSI}

Adawiyah, R., Rizki, M.I. 2018. Aktivitas Antioksidan Ekstrak Etanol Akar Kalakai (Stenochlaena palustris Bedd) Asal Kalimantan Tengah. Jurnal Pharmascience. 5(1):71 - 77. http://dx.doi.org/10.20527/jps.v5i1.5788

Dinas Kesehatan Provinsi Kalimantan Selatan. 2021. Informasi Terbaru Covid 19 di Kalimantan Selatan $24 \quad$ Juni 2021. http://dinkes.kalselprov.go.id/berita/inform asi-terbaru-covid-19-di-kalimantan-selatan24-juni-2021.html

Fahruni, Handayani, R., Novaryatiin, S. 2018. Potensi Tumbuhan Kelakai (Stenochlaena palustris (Burm.F.) Bedd.) asal Kalimantan Tengah sebagai Afrodisiaka. Jurnal Surya Medika (JSM). 3(2):144-153.

https://doi.org/10.33084/jsm.v3i2.114

Handayani, D., Hadi, D.R., Isbaniah, F., Burhan, B., Agustin, H. 2020. Corona Virus Disease 2019. Jurnal Respirologi Indonesia. 40(2):119-129. https://doi.org/10.36497/jri.v40i2.101

Harapan, H., Itoh, N., Yufika, A., Winardi, W., Keam, S., Te, H., Megawati, D., Hayati, Z., Wagner, A.L., Mudatsir, M. 2020. Coronavirus disease 2019 (COVID-19): A literature review. Journal of Infection and Public Health. 13(5):667-673. https://dx.doi.org/10.1016/j.jiph.2020.03.019

Indrayanti, A.L., Hidayati, N., Hanafi, N. 2016. Studi Kasus Analisis Pendapatan Usaha Keripik Kalakai Imur di Kota Palangka Raya. Daun: Jurnal Ilmiah Pertanian dan Kehutanan. 3(1):1-6. https://doi.org/10.33084/daun.v3i1.154

Juliani, E., Saragih, B., Syahrumsyah, H. 2019. Pengaruh Formulasi Daun Kalakai (Stenochlaena palustris (Burm. f) Bedd) dan AsmJahe (Zingiber officinale rosc) Terhadap Sifat Sensoris Dan Aktivitas Antioksidan Minuman
Herbal. In Prosiding Seminar Nasional Ke-2 Tahun 2019 Balai Riset dan Standardisasi Industri Samarinda. Samarinda, Balai Riset dan Standardisasi Industri Samarinda. pp. A53A61.

Mahdiyah, D., Sari, A., Palimbo, A., Sari, P.V., Al Kahfi, R., Nurdin, F. 2021. Pemanfaatan Kekayaan Hayati Lokal: Teh Fermentasi Dari Kelakai (Stenochlaena palustris) Sebagai Produk Kewirausahaan. Jurnal Pengabdian Al-Ikhlas Universitas Islam Kalimantan Muhammad Arsyad Al Banjary. 7(1):124-130. http://dx.doi.org/10.31602/jpaiuniska.v7i1.5 440

Mashar, H.M., Annah, I. 2020. Cytotoxicity of Kalakai (Stenochlaena palustris) Extract to MCF-7 Breast Cancer Cell. Jurnal Fitofarmaka Indonesia. 7(3):5-9.

https://doi.org/10.33096/jffi.v7i3.590

Ryadha, R.S., Aulia, N., Batara, B. 2021. Potensi RempahRempah sebagai Minuman Fungsional Sumber Antioksidan dalam Menghadapi Pandemi Covid-19. Jurnal Sosial, Budaya dan Sains (ABDI). 3(1):30-42.

Sen, S., Chakraborty, R. 2011. The Role of Antioxidants in Human Health. Oxidative Stress: Diagnostics, Prevention, and Therapy. 1:1-37. https://doi.org/10.1021/bk-2011-1083.ch001 